\title{
Correction to: protease-activated receptors (PARs): mechanisms of action and potential therapeutic modulators in PAR-driven inflammatory diseases
}

Dorothea M. Heuberger ${ }^{1,2}$ and Reto A. Schuepbach ${ }^{1 *}$

\section{Correction to: Thrombosis Journal (2019) 17:4. http://doi.org/10.1186/s12959-019-0194-8}

Following the publication of this article [1], the authors reported an incorrect citation in the following sentence in the "Metalloproteases" sub-section:

"Similarly, MMP-2 cleaves human PAR1 and enhances platelet activation [91], and MMP-3, MMP-8, and MMP-9 were shown to induce platelet activation via PAR1 [92]."

The correct citation for reference 92 in this sentence is: Lee EU, Woo MS, Moon GP, Baek MC, Choi IY, Kim WK, Junn E and Kim HS. $\alpha$-Synuclein Activates Microglia by Inducing the Expressions of Matrix Metalloproteinases and the Subsequent Activation of Protease-Activated Receptor-1. J Immunol. 2010, ji_0903480.

For further clarification, this sentence should read as follows:

"Similarly, MMP-2 cleaves human PAR1 and enhances platelet activation [91], and MMP-3, MMP-8, and MMP-9 were shown to cleave and activate PAR1 peptide at thrombin cleavage site R41 [92]."

\section{Author details}

'Institute of Intensive Care Medicine, University Hospital Zurich, University of Zurich, Zurich, Switzerland. '2Surgical Research Division, University Hospital

Zurich, University of Zurich, Zurich, Switzerland.

Published online: 06 November 2019

\section{Reference}

1. Heuberger and Schuepbach. Protease-activated receptors (PARs): mechanisms of action and potential therapeutic modulators in PAR-driven inflammatory diseases. Thrombosis Journal (2019) 17:4 https://doi.org/10. 1186/s12959-019-0194-8

The original article can be found online at https://doi.org/10.1186/s12959019-0194-8

* Correspondence: reto.schuepbach@usz.ch

'Institute of Intensive Care Medicine, University Hospital Zurich, University of Zurich, Zurich, Switzerland

Full list of author information is available at the end of the article

(c) The Author(s). 2019 Open Access This article is distributed under the terms of the Creative Commons Attribution 4.0 International License (http://creativecommons.org/licenses/by/4.0/), which permits unrestricted use, distribution, and reproduction in any medium, provided you give appropriate credit to the original author(s) and the source, provide a link to the Creative Commons license, and indicate if changes were made. The Creative Commons Public Domain Dedication waiver (http://creativecommons.org/publicdomain/zero/1.0/) applies to the data made available in this article, unless otherwise stated. 